\title{
KEBERMAKNAAN HIDUP PADA MAHASISWA RANTAU DI INDONESIA
}

\section{THE MEANING OF LIFE ON INDONESIAN OVERSEAS STUDENTS}

\author{
Suprastowo Damarhadi ${ }^{1}$, Mahmud Junianto ${ }^{2}$, Siti Nur Indasah ${ }^{3}$, Nina Zulida Situmorang ${ }^{4}$ \\ ${ }^{1234}$ Universitas Ahmad Dahlan \\ ${ }^{1}$ kimdamar@gmail.com, ${ }^{2}$ mahmudjunianto191@gmail.com, ${ }^{3}$ nurindasyahn@ gmail.com, \\ ${ }^{4}$ nzsitumorang@gmail.com
}

\begin{abstract}
Abstrak
Yogyakarta merupakan tempat belajar bagi para mahasiswa yang berasal dari berbagai daerah di Indonesia. penelitian ini bertujuan untuk mengetahui makna hidup yang dimiliki mahasiswa rantau di Indonesia. Metode yang digunakan adalah kualitatif dengan pendekatan fenomenologi. Responden sebanyak 77 mahasiswa yang dipilih menggunakan teknik purposive menjawab pertanyaan yang diajukan menggunakan kuesioner dan wawancara. Hasil analisis pada penelitian ini menunjukan bahwa makna hidup merupakan sebuah kebermanfaat $(27,6 \%)$, proses $(24,63 \%)$, dan beribadah $(14,24 \%)$ menempati persentase tertinggi, kemudian diikuti kebersyukuran $(13,35 \%)$, kebahagiaan $(11,27 \%)$, ikhlas $(8,91 \%)$.
\end{abstract}

Kata Kunci: makna hidup, mahasiswa, rantau

\begin{abstract}
Yogyakarta is a place of learning for students who come from various regions in Indonesia. This study aims to determine the meaning of life that is owned by overseas students in Indonesia. The method used is qualitative with the indigenous psychology approach. Respondents as many as 77 students were selected using purposive techniques to answer questions posed using questionnaires and interviews. The results of the analysis in this study note that the meaning of life in overseas students in Yogyakarta is a benefits (27.60\%), process $(24.63 \%)$, worship $(14.24 \%)$ have a ranks highest, then thankfulness (13.35\%), happiness $(11.27 \%)$, sincere $(8.91 \%)$.
\end{abstract}

Keywords: meaning of life, overseas, students

\section{PENDAHULUAN}

Pendidikan merupakan sarana untuk mencerdaskan kehidupan bangsa dengan mencetak generasi muda yang handal. Tentunya lembaga pendidikan seperti perguruan tinggi mempunyai andil dan berperan didalamnya. Daerah Istimewa Yogyakarta merupakan tempat pendidikan dengan banyaknya perguruan tinggi yang ada, sehingga banyak mahasiswa di Indonesia yang menuntut ilmu di Yogyakarta. Hal tersebut semakin menarik minat mahasiswa dari luar daerah untuk merantau ke Yogyakarta dengan tujuan untuk menuntut ilmu dan menyelesaikan jenjang pendidikan yang diinginkannya. Astuti (2013), menyebutkan bahwa sebagian orang harus merantau ke luar daerahnya untuk mendapatkan pendidikan yang lebih tinggi dengan kualitas pendidikan yang lebih baik. Pendidikan yang lebih baik disertai kualitas pendidikan yang sesuai dengan perkembangan zaman diharapkan mampu memberikan kontribusi secara luas pada segala aspek kehidupan melalui mahasiswa.

Mahasiswa yang menuntut ilmu pada perguruan tinggi tidak lepas dari permasalahan kehidupan yang selalu menyertainya. Banyak hal yang mempengaruhi munculnya permasalahan

DOI :

URL : http://ejurnal.mercubuana-yogya.ac.id/index.php/psikologi/index

Email : insight@mercubuana-yogya.ac.id 
tersebut. Mahasiswa yang mengalami permasalahan tentu tidak dapat mencapai hasil maksimal dalam pencapaian target belajarnya, sehingga mahasiswa perlu mempunyai kemmampuan untuk mengatur waktunya dengan baik sehingga aktifitas/kegiatannya dapat berjalan dengan baik. Permasalahan yang dihadapi oleh mahasiswa akan menjadi nilai dalam dirinya untuk menemukan kebermaknaan hidup. Mahasiswa yang mampu menyelesaikan permasalahannya dengan baik maka telah mampu menemukan pemaknaan hidup (Hidayat, 2018). Makna hidup adalah sesuatu yang dianggap penting, memberikan nilai secara khusus bagi manusia, dan hal tersebut didambakan pada kehidupannya (Bastaman, 2007).

Mahasiswa akan berusaha menemukan makna hidup pada perjalanan hidupnya, penemuan makna hidup jika berhasil maka membuat kehidupan menjadi berharga sehingga akan memunculkan perasaan yang bahagia. Mahasiswa yang dalam kesehariannya mempunyai banyak permasalahan seperti tugas yang banyak dan masih banyak permasalahan pelik lainnya tentu menyebabkan kesulitan untuk menemukan makna hidupnya, hal ini sesuai penelitian Stegar, Kashdan, Sullivan, dan Lorentz (2008), penelitiannya menyebutkan orang-orang yang kurang mempunyai makna dalam hidupnya akan berusaha mencarinya, akan tetapi pencarian makna tersebut akan sulit ditemukan dalam hidupnya.

Frankl (2004) dalam teorinya mendefinisikan bahwa makna hidup merupakan proses penemuan hakekat yang sangat berarti bagi seseorang. Makna hidup adalah sesuatu yang dianggap penting dan memberikan nilai khusus pada seseorang. Menurut Frankl (2004) sumber kebermaknaan hidup itu diperoleh salah satunya dengan creative value. Nilai ini dapat diraih dengan cara seseorang melakukan suatu kegiatan semisal bekerja, berkarya, menjalankan tugas dengan penuh tanggung jawab, dan berbuat kebaikan. Karena teori tersebut merupakan hasil dari sebuah pemikiran lokal di Austria tentunya akan berbeda maksud kebermaknaan hidup jika diterapkan di Indonesia yang memiliki perbedaan yang mendasar pada kebudayaan. Oleh sebab itu peneliti akan mencari nilai indigenous atau nilai orisinil tentang kebermaknaan hidup di Indonesia.

Penelitian ini dilakukan pada mahasiswa rantau di Yogyakarta. Mahasiswa rantau akan berada pada lingkungan yang baru, bertemu dengan orang-orang baru dan melakukan sosialisasi yang mana bentuk afiliasi tersebut akan merubah cara pandangnya terhadap hidup dan menemukan kebermaknaan hidup yang baru (Bastaman, 2007). Studi pendahuluan dilakukan dengan mewawancarai 10 mahasiswa rantau pada perguruan tinggi di Yogyakarta dan didapatkan hasil diantaranya 8 mahasiswa menyatakan belum menemukan makna hidupnya secara pasti dan terdapat keraguan menjawab sumber-sumber kebermaknaan hidupnya sedangkan 2 mahasiswa lainnya secara jelas memberikan jawaban bahwa makna hidupnya adalah dapat memberikan manfaat pada orang lain dan mempunyai kebahagiaan dalam perjalanan hidupnya. Selain contoh diatas, peneliti meyakini bahwa masih banyak mahasiswa rantau pada perguruan tinggi di Yogyakarta yang sampai saat ini belum menemukan makna hidupnya tersendiri. Maka berdasarkan pemaparan di atas, peneliti tertarik untuk mengkaji terkait makna hidup pada 
mahasiswa rantau di Yogyakarta. Tujuan penelitian mengetahui dan menemukan makna hidup pada mahasiswa rantau di Yogyakarta, sehingga dapat memberikan manfaat pada mahasiswa yaitu membuat kehidupan menjadi berharga sehingga membuatnya dapat menyelesaikan permasalahan yang dialami serta dapat menyelesaikan proses belajar selama berada di Yogyakarta.

\section{METODE}

Penelitian ini menggunakan pendekatan metode kualitatif dengan pendekatan fenomenologi. Responden merupakan mahasiswa rantau di Yogyakarta yang berasal dari berbagai daerah di Indonesia. Berjumlah 77 orang dengan rentang usia 19-26 tahun. Pemilihan responden dalam penelitian ini menggunakan teknik sampling yaitu teknik penentuan responden dengan pertimbangan tertentu, didasarkan atas ciri-ciri tertentu yang dipandang mempunyai sangkut paut yang erat dengan ciri-ciri populasi yang sudah diketahui sebelumnya (Azwar, 2013).

Pengumpulan data menggunakan kuesioner terbuka mengenai makna hidup dengan pertanyaan "Jelasakan lima makna hidup dan alasannya?" dengan jawaban esai yang terdiri dari lima pernyataan makna hidup dan alasannya. Dengan adanya jawaban dari responden maka dilakukan tahapan pengkodean untuk mendapatkan kata kunci atas jawaban alasan makna hidup yang telah dituliskan oleh responden. Dilanjutkan dengan tahapan kategorisasi dengan tujuan untuk mendapatkan hasil yang lebih mengerucut tentang makna hidup pada mahasiswa rantau di Yogyakarta.

\section{HASIL DAN PEMBAHASAN}

Berdasarkan angket yang telah dibagikan, maka diperoleh 77 responden penelitian. Peneliti menyediakan lima kolom yang harus diisi responden terkait makna hidup. Jumlah jawaban responden bervariasi dengan ada yang menjawab dua alasan,tiga alasan, empat alasan, dan lima alasan. Sebanyak 77 responden penelitian, diperoleh 337 makna hidup dan alasannya.

\begin{tabular}{lcc}
\multicolumn{3}{c}{ Tabel 1. Kategorisasi Makna Hidup } \\
\hline \multicolumn{1}{c}{ Kategori } & Makna & $\mathbf{\%}$ \\
\hline Ibadah & 48 & $14,24 \%$ \\
Syukur & 45 & $13,35 \%$ \\
Manfaat & 93 & $27,60 \%$ \\
Proses & 83 & $24,63 \%$ \\
Bahagia & 38 & $11,27 \%$ \\
Ikhlas & 30 & $8,91 \%$ \\
Total & $\mathbf{3 3 7}$ & $\mathbf{1 0 0 \%}$ \\
\hline
\end{tabular}

Berdasarkan table di atas maka diketahui bahwa kategori makna hidup tertinggi adalah kebermanfaat $(27,6 \%)$, kemudian diikuti proses $(24,63 \%)$, beribadah $(14,24 \%)$, kebersyukuran $(13,35 \%)$, kebahagiaan $(11,27 \%)$, dan ikhlas $(8,91 \%)$. Pemrosesan hasil kategorisasi dapat dilihat pada tabel berikut. 
Tabel 2. Contoh Proses Kategorisasi

\begin{tabular}{|c|c|c|}
\hline Pemaknaan & Perumusan Makna & Kategorisasi \\
\hline $\begin{array}{l}\text { Dengan perjalanan hidup yang baik tidak } \\
\text { ada rintangan dan semua bisa diatasi maka } \\
\text { hidup akan terasa tenang. }\end{array}$ & $\begin{array}{l}\text { Makna hidup } \\
\text { dideskripsikan sebagai } \\
\text { perjalanan hidup }\end{array}$ & Proses \\
\hline $\begin{array}{l}\text { Akhirat ujung kehidupan adalah kematian. } \\
\text { Jadi siapkan amal untuk akhirat bukan } \\
\text { duniawi saja }\end{array}$ & $\begin{array}{lr}\text { Makna } & \text { hidup } \\
\text { dideskripsikan } & \\
\text { berorientasi } & \text { pada } \\
\text { tujuan hidup } & \text { secara } \\
\text { rohani. } & \end{array}$ & Ibadah \\
\hline
\end{tabular}

Berdasarkan hasil di atas mengisyaratkan pencapaian makna hidup telah menunjukkan karakternya sesuai dengan kategorisasi yang telah berhasil dilakukan berdasarkan hasil angket yang disebar. Makna hidup tidak hanya dirasakan individu yang merasakan kebahagiaan dalam hidupnya, namun lebih mengarah pada segala kondisi yang terjadi pada individu itu sendiri. Sehingga dapat disimpulkan bahwa makna hidup merupakan motivasi, tujuan dan harapan yang harus dimiliki oleh setiap individu yang dalam pencapaiannya harus dilakukan dengan usaha yang maksimal.

Upaya penemuan makna hidup yang berasal dari kemurnian suatu daerah maka menggunakan metode pendekatan indigenous psychology dengan berupaya mengkaji makna hidup pada mahasiswa rantau di Yogyakarta. Psikologi indigenous adalah studi ilmiah, dan yang dirancang untuk rakyatnya (Park dan Kim, 2006). Lebih lanjut Uichol (2006), menyatakan bahwa tujuan dasar indigenous psychology adalah mengembangkan sistem pengetahuan ilmiah yang secara efektif merefleksikan, mendeskripsikan, atau memahami aktivitas psikologis dan perilaku di dalam konteks native mereka, yaitu kerangka budaya yang relevan, serta kategori dan teori yang didapat dari budaya di daerah tertentu.

Dengan dasar pemikiran tersebut, maka metode penelitian kualitatif dipandang lebih sesuai untuk menerapkan pendekatan indigenous psychology, karena lebih bersifat universal dan bermanfaat untuk dapat digunakan mempelajari karakteristik budaya suatu daerah tertentu. Metode kualitatif lebih dapat memfasilitasi strategi penelitian emic (sudut pandang budaya) yang memberikan penekanan pada interpretasi dari sudut pandang responden di daerah tertentu. Sehingga berdasarkan uraian hasil pada tabel di atas dapat digambarkan kebermaknaan hidup pada mahasiswa rantau di Yogyakarta secara khas adalah ibadah, syukur, manfaat, proses, bahagia, ikhlas. Penelitian yang mengkaji makna hidup pada mahasiswa rantau di Yogyakarta jika dilakukan pada daerah lain tentunya dimungkinkan akan memberikan hasil yang berbeda. Hal ini disebabkan karakteristik daerah yang satu dengan yang lainnya berbeda baik dari sisi budaya, sejarah daerah, keunikan daerah, geografis daerah, dll yang akan mempengaruhi daripada makna hidup mahasiswa rantau yang berada pada daerah tersebut. 


\section{Ibadah}

Responden menyatakan bahwa mereka memaknai hidupnya sebagai ibadah yaitu menjalankan perintahNya dan menjauhi laranganNya. Ibadah secara bahasa (etimologi) berarti merendahkan diri serta tunduk. Sedangkan menurut syara' (terminologi), ibadah mempunyai banyak definisi, tetapi makna dan maksudnya satu. Ibadah dideskripsikan seperti dengan ibadah hati, lisan, dan anggota badan, sasa khauf (takut), raja' (mengharap), mahabbah (cinta), tawakkal (ketergantungan), raghbah (senang), dan rahbah (takut) adalah ibadah qalbiyah (yang berkaitan dengan hati).

Alasan makna hidup yang muncul diantaranya adalah hidup untuk bekal mati, kesempurnaan hanya milik Allah SWT, selalu beriman kepada Aallah SWT, selalu bertakwa kepada Allah SWT, dan hidup bersama Allah beserta ridhoNya. Ibadah merupakan bagian penting dalam kehidupan manusia dan menunjukkan eksistensi agama di dalam pribadi manusia itu sendiri (Pimpinan Pusat Muhammadiyah, 2017).

\section{Syukur}

Responden menyatakan bahwa mereka memaknai hidupnya sebagai syukur. Syukur mempunyai kata dasar syakara yaitu terimakasih, sedangkan secara bahasa mempunyai arti pujian kepada yang telah berbuat baik atas apa yang dilakukan kepadanya. Syukur merupakan bagian dari emosi positif yang berarti ada hal yang menyenangkan didalamnya. Syukur merupakan salah satu dari bentuk kecerdasan manusia yang apabila mampu melakukannya maka akan mendapatkan ketenangan dan ketentraman jiwa sehingga individu akan tenang dan tegar dalam menghadapi permasalahan hidupnya (Takdir, 2017). Syukur merupakan contoh emosi yang menyenangkan atau positif yang sebelumnya telah terbentuk sebuah persepsi bahwa individu akan memperoleh manfaat dari yang akan dilakukan orang lain dan dapat juga dipersepsikan setelah mendapatkan manfaat dari orang lain (McCullough, Kimeldorf, \& Cohen, 2008). Syukur mempunyai banyak sekali contoh dalam kehidupan individu baik yang bersifat personal maupun berkaitan dengan keberadaan Tuhan, pengungkapan rasa syukur dapat berupa lisan maupun dengan tindakan .

Syukur oleh responden dideskripsikan dengan berbagai alasan pengungkapan makna hidup misalnya kita harus selalu beryukur menjalani hidup ini, Bersyukur menikmati apa yang udah diberikan Allah SWT, Kondisi fisik lengkap dan akal yang sehat, Bersyukur tanpa rasa syukur tidak akan pernah merasa cukup, Selalu memperbaiki diri dan bersyukur, dan Dengan bersyukur akan merasa cukup, sesuatu yang berlebihan itu tidak baik. Contoh pengungkapan syukur ini sesuai dengan karakteristik wilayah Yogyakarta yang dikenal dengan banyaknya pondok pesantren dan perguruan tinggi Muhammadiyah sehingga mahasiswa makna hidupnya lebih mengarah kepada keberadaan Tuhan sebagai motivasi timbulnya respon syukur, hal ini sesuai dengan penelitian yang dilakukan oleh Haryanto (2016), menyebutkan bahwa syukur lebih menekankan 
pada keberadaan Tuhan sebagai motif dalam memunculkannya syukur dan konsep syukur lebih mengarah pada ranah agama.

\section{Manfaat}

Responden memberikan deskripsi alasan pengungkapan makna hidup berupa manfaat, dapat dicontohkan yaitu Bukan sekedar hidup, tapi harus membawa perubahan yang positif dilingkungan, Hal ini membuktikan bahwa diri pernah ada didunia sebagai bentuk eksistensi, contoh lainnya seperti; Karena dengan menjadikan hidup bermanfaat maka akan lebih bernilai baik itu bagi diri sendiri maupun orang lain disekitar kita. Hal ini sesuai dengan konsep makna dalam kehidupan menunjukkan bagaimana individu memandang hidup mereka sebagai makhluk signifikan dan bermakna; upaya atau keinginan mereka untuk memiliki tujuan dalam hidup dan membentuk dan memperkuat tujuan itu (Steger, Kashdan, Sullivan \& Lorentz, 2008).

\section{Proses}

Proses digambarkan dengan kehidupan yang pada dasarnya adalah sebuah proses yang panjang dengan perkembangan-perkembangan yang menyertainya. Perkembangan dimaksud baik fisik maupun psikis. Perkembangan psikis terbentuk melalui proses dalam diri individu itu sendiri dengan adanya interaksi dengan lingkungan sosial dan alam (Santrock, 2011). Proses menjadi salah satu alasan pengungkapan makna hidup oleh responden. Terdapat banyak alasan pengungkapan yang digambarkan sebagai bagian dari peristiwa dalam diri responden yang dilalui dan akhirnya responden dapat menemukan makna hidupnya. Santrock (2011) proses yang terjadi didalamnya ditemukan berkaitan dengan lingkungan yang mempengaruhi adanya penemuan makna hidup yang berarti ciri khas atau corak daerah memberikan andil atau pengaruh terhadap pembentukan proses itu sendiri.

\section{Bahagia}

Responden mengungkapkan alasan makna hidup dengan bahagia. Pada responden menggambarkan kebahagiaan sebagai terwujudnya harapan, keinginan, cita-cita, dan tidak adanya kegagalan. Bahagia merupakan salah satu bentuk emosi positif dan mempunyai banyak pengertian dari banyak ahli yang melakukan penelitian. Penelitian tersebut berusaha mengungkap mengenai konsep kebahagiaan dan telah banyak dilakukan penelitian melalui berbagai perspektif. Masingmasing perspektif memberikan penjelasan yang berbeda-beda mengenai apa yang dimaksud dengan kebahagiaan itu sendiri, yang pada akhirnya muncul hasil yang berbeda-beda pula mengenai bagaimana kebahagiaan itu bisa dicapai. Kebahagiaan memiliki konsep yang luas, seperti emosi positif, pengalaman yang menyenangkan, rendahnya suasana hati yang negatif, dan dimilikinya kepuasan hidup yang tinggi (Diener, Suh, Lucas, \& Smith 2005). 


\section{Ikhlas}

Ikhlas digambarkan oleh responden dengan perbuatan dan motif dari individu melakukan perbuatan itu sendiri. Ikhlas menjadi pengungkapan makna hidup oleh responden yang memberikan corak tersendiri. Bagaimana kemudian ikhlas dapat menjadi bagian dari makna hidup responden. Ikhlas berasal dari kata kholasho yang memiliki arti murni, bersih. Hal ini merujuk pada pemurnian niat dalam menjalani rutinitas kehidupan, hanya demi mencari kedekatan kepada Tuhan (Qalami, 2003). Berdasarkan hasil yang diperoleh ditunjukkan iklhas lebih ditekankan berkaitan dengan perilaku dan sikap yang dimiliki oleh responden serta mengarah pada nuansa religiusitas. Hal ini sesuai dengan hasil penelitian yang terdahulu bahwa iklhas merupakan kondisi yang berkaitan dengan proses berideologi sebagai hamba Tuhan (Chizanah, 2009).

\section{KESIMPULAN}

Kesimpulan yang didapatkan dalam penelitian ini dimana dimensi-dimensi/ indikatorindikator penyusun dari variabel laten konflik pekerjaan-keluarga menunjukkan bahwa semua nilai loading factor berpengaruh secara signifikan (unidimensional) terhadap variabel-variabel laten pada Confirmatory Factor Analysis (CFA). Kontribusi terbesar pada variabel konflik pekerjaankeluarga adalah dimensi rekan kerja dan yang terendah adalah beban kerja.

\section{DAFTAR PUSTAKA}

Badan Pusat Statististik. (2009). Keadaan angkatan kerja di Indonesia. Jakarta: CV Petratama Persada.

Erdwins.C.J, Buffardi.L.C, Casper.W.J., \& O`Brien.A.S. (2001).The Relationship of women`s role strain to social support, role satisfaction and self-efficacy. Family Relations, 50(3), 230-238.

Fathurochman, Minza, W. M., \& Nurjaman, T.A. (2017). Memahami dan Mengembangkan Indigenous Psychology. Yogyakarta : Pustaka Pelajar - Fakultas Psikologi UGM.

Greenhaus, J. H., \& Beutell, N. J. (1985). Sources of conflict between work and family roles. Academy of Management Review, 10, 76-88.

Hammer.L. B., Neal, M. B., Newson, J. T., Brockwood. K. J., \& Colton, C. L. (2005). A longitudinal study of the effects of dual-earner cuoples utilization of family-friedly workplace supports on work and family outcomes. Journal of Applied Psychology, 90(4), 799-810.

Handayani, C.S., \& Novianto, A. (2004). Kuasa wanita Jawa. Yogyakarta: LKiS.

Hill, E. J. (2005). Work-family facilition and conflict, working fathers and mothers, work-family stressors and support. Journal of Family Issues, 26, 793-819.

Huang, Y. H., Hammer. L. B, Neal. M. B., \& Perrin, N. A. (2004). The relationship between workto-family conflict and family-to-work conflict: A longitudinal study. Journal of Family and Economic Issues, 25(1), 79-100. 
Kim, J. L. S., \& Ling. C. S. (2001). Work-family conflict of women entrepreneurs in Singapore. Women in Management Review, 16(5/6), 204-221.

Koentjaraningrat. (1974). Manusia dan kebudayaan di Indonesia. Jakarta: Djambatan.

Magnis-Suseno, F. (1985). Etika Jawa: Sebuah analisa falsafi tentang kebijaksanaan hidup Jawa. Jakarta: PT Gramedia.

Noor, M. N. (2002). Work-family conflict, locus of control, and women`s well-being: Tests of altenative pathways. The Journal of Social Psychology, 142(5), 645-662.

Noor, M. N. (2004). Work-family conflict, work-family-role salience, and women`s well-being. The Journal of Social Psychology, 144(4), 389-405.

Voydanoff, P. (2004). The Effects of work demands and resources on work-to-family conflict and facilitation. Journal of Marriage and the Famiy, 66, 398-412. 